\title{
Kesiapan SDM Dan Regulasi Pengelolaan DAUT Di Kota Payakumbuh Tahun Anggaran 2019
}

\author{
Daraidimar \\ Analis Keuangan Pusat dan Daerah \\ Email : daraidimar@payakumbuhkota.go.id
}

\begin{abstract}
ABSTRAK
Penyediaan Sumber Daya Manusia(SDM) dan regulasi yang tidak memadai akan berakibat tidak optimalnya penyerapan Dana Alokasi Umum(DAU) Tambahan Tahun 2019. Analisis data menggunakan data sekunder dari Pemerintah Kota Payakumbuh dengan menggunakan metode deskriptif kualitatif. Hasil analisa menunjukkan bahwa SDM pengelola keuangan DAUT tahun 2019 belum tersedia sesuai kebutuhan dan regulasi yang mengatur proses penganggaran, penatausahaan dan pelaporan, belum ditetapkan dengan peraturan Walikota. Berdasarkan hasil analisis tersebut, maka pemerintah Kota Payakumbuh harus menyiapkan regulasi DAUT Tahun 2019 sehingga penyesuaian kebutuhan SDM dan mekanisme pengelolaan keuangan berjalan dengan baik. Dengan demikian serapan anggaran dapat lebih maksimal.
\end{abstract}

Kata Kunci ; SDM, Regulasi, DAUT;

\section{ABSTRACT}

The Provision of Human Resources (HR) and inadequate regulations will result in not optimal absorption of the Additional General Allocation Fand (DAU) for 2019. Data analysis uses secondary data from the Payakumbuh City Government using qualitative descriptive methods. Human resources managing the Additional DAU finances in 2019 are not yet available according to the needs and the regulations governing the budgeting, administration and reporting processes have not been determined by a Mayor regulation. Based on the results of the analysis, the Payakumbuh City government must prepare an Additional DAU regulation for 2019 so that the adjustment of human resource needs and financial management mechanisms works well. Thus the budget absorption can be maximized.

Keywords ; HR ; Regulations ; Additional DAU ;

\section{PENDAHULUAN}

Alokasi Anggaran, sesuai dengan UU No.12 Tahun 2018 tentang APBN TA. 2019, kepada daerah diberikan alokasi anggaran tambahan, dengan sebutan Dana Alokasi Umum Tambahan disingkat dengan DAUT. Dana tersebut dituangkan berupa Kegiatan yang bertujuan untuk Pembangunan Sarpras Kelurahan yang disingkat dengan Pembangunan Sarpras Kelurahan dan kegiatan untuk Pemberdayaan Masyarakat dikelurahan yang disingkat dengan Pemberdayaan Masyarakat Kelurahan.

Berdasarkan Peraturan Menteri Keuangan No187/PMK.07/2018, Pemerintah Kota Payakumbuh menganggarkan DAUT sebesar Rp.17.396.486.000 dengan rincian dana yang di alokasikan untuk kegiatan Pembangunan Sarpras Kelurahan sebesar Rp.12.433.569.882.- dan kegiatan Pemberdayaan Masyarakat dikelurahan sebesar Rp.4.962.916.118.-, dengan 
capaian (tahap I dan Tahap II) adalah sebesar Rp.14.040.710.005.- yaitu 80,71\%.

Tujuan penulisan adalah untuk mengetahui kesiapan Sumber Daya Manusia (SDM) sebagai pengelola DAUT Tahun 2019 dengan regulasi yang mendukung pengelolaan DAUT tahun 2019 di Kota Payakumbuh.

\section{METODE PENELITIAN}

Metode yang digunakan adalah deskriptif kualitatif, mengumpulkan data dengan wawancara, dokumentasi dan penelitian kepustakaan.

\section{PENGERTIAN}

\subsection{Pengertian Sumber Daya Manusia}

Mathis dan Jackson, menjelaskan bahwa tercapainya tujuan organisasi/perusahaan sesuai keinginan, maka dibutuhkan pesonil yang memliki keahlian sehingga dapat berfungsi efektif serta efisien sesuai dengan tujuan organisasi. (jackson, 2006) M.T.E.Hariandja menjelaskan bahwa SDM adalah salah satu faktor yang penting pada perusahaan sehingga dibutuhkan SDM yang dikelola dengan baik dan efektivitas guna meningkatkan efisiensi perusahaan. (Hariandja, 2002)

\subsection{Pengertian DAU Tambahan (DAUT)}

DAUT yang diberikan pada TA 2019 untuk Pemerintah Kab/Kota guna Pembangunan Sarpras Kelurahan dan Pemberdayaan Masyarakat dikelurahan .

\subsection{Pengertian Regulasi Pengelolaan DAUT}

Pengelolaan DAUT berdasarkan UU No.12 Tahun 2018 dan secara teknis diatur dengan Peraturan Menteri Keuangan No.187/PMK.07/2018, meliputi :

1) Perencanaan, kegiatan dari DAUT berguna untuk membiayai pelayanan sosial dasar berdampak langsung pada peningkatan kualitas hidup masyarakat dikelurahan yang digunakan untuk peningkatan kapasitas dan kapabilitas masyarakat di tingkat kelurahan dengan mendayagunakan potensi dan sumber daya sendiri, berdasarkan hasil musyawarah dengan Lembaga Pemberdayaan Masyarakat dikelurahan .

2) Pengangaran, berdasarkan hasil penilaian dalam penghitungan DID pada kelompok pelayanan dasar publik dengan mengelompokkan Daerah kab/kota menjadi 3 (tiga) sebagai berikut:

a. Kelompok Baik ; yaitu DAUT sebesar Rp.352. 941.000,- per kelurahan.

b. Kelompok Perlu ditingkatkan ; yaitu DAUT sebesar Rp.370.138.000,- per kelurahan.

c. Kelompok Sangat perlu ditingkatkan ; yaitu DAUT sebesar Rp.384.000.000,- per kelurahan.

3) Penatausahaan, penyaluran DAUT memenuhi ketentuan berikut :

1. Tahapan :

a. Tahap*I dilaksanakan bulan Januari dan berakhir pada Mei 2019, setelah Walikota menyampaikan dokumen.

b. Tahap II dilaksanakan paling lambat bulan Agustus 2019, setelah Kepala Daerah 


\begin{abstract}
menyampaikan jumlah realisasi penyerapan DAUT tahap I minimal 50\% dari dana yang diterima pada Kas Daerah .
\end{abstract}

2. Persyaratan penyaluran DAUT disampaikan berupa dokumen dengan ketentuan sebagai berikut:

a. Tahap*I disampaikan s.d minggu II bulan Mei 2019

b. Tahap II s.d tanggal 16 Agustus 2019, apabila Pemerintah Kab/Kota belum menyampaikan dokumen persyaratan tersebut, maka penyaluran DAUT Tahap I dan tahap II tidak akan disalurkan.

3. Dalam penyampaian persyaratan penyaluran tahap I, Pemerintah Kab/Kota agar menyertakan rekapitulasi anggaran kelurahan.

4. Pelaksanaan Anggaran dilakukan oleh Pejabat Penatausahaan Keuangan Pembantu di Kelurahan (KPA, PPK dan PPTK, Bendahara Pembantu, Pejabat Pengadaan dan PjPHP).

4) Pelaporan dan Pertanggung Jawaban

Laporan pertanggungjawaban DAUT Tahun 2019 dan sisa dana yang bersifat earmarked, disampaikan paling lambat bulan Maret 2020 ke Direktorat Jendral Perimbangan Keuangan cq Direktorat Dana Perimbangan.
Laporan realisasi penggunaan anggaran kegiatan Pembangunan Sarpras Kelurahan dan Pemberdayaan Masyarakat dikelurahan (bersumber dari APBD) disampaikan kepada melalui Gubernur,Walikota dan camat setiap semester.

5) Pembinaan danpengawasan

a. Penganggaran, pembinaan danpengawasan dialokasikan pada Organisasi Perangkat Daerah adalah melakukan fungsi pembinaan dan pengawasan sesuai dengan bidang masing-masing.

b. Pemerintah Daerah Kab/Kota dapat menugaskan fasilitator dari perangkat daerah teknis, untuk membantu tugas kelompok masyarakat atau organisasi kemasyarakatan dalam persiapan, pelaksanaan dan pengawasan swakelola. Dalam hal pelaksanaan pengadaan barang/jasa melalui mekanisme swakelola. Sisa anggaran DAUT Tahun Anggaran 2019 ini yang masih berada diRekening Kas Daerah maupun rekening Kelurahan, akan menjadi SiLPA yang dapat diperhitungkan pada alokasi untuk Kegiatan tahun anggaran selanjutnya.

SDM adalah Aparat Sipil Negara (ASN) yang bertugas mengelola keuangan di kelurahan sebagai KPA, PPK dan PPTK, Bendahara Pembantu , Pejabat pengadaan dan PjPHP. 
Regulasi pengelolaan

keuangan DAUT merupakan kaedah aturan dan ketentuan yang dibuat untuk mengatur petunjuk yang digunakan dalam menata administrasi keuangan DAUT yang harus dijalankan serta dipatuhi .

Pengelolaan keuangan DAUT merupakan proses yang diawali dengan perencanaan, dilanjutkan dengan penganggaran, dilaksanakan dengan penatausahaan, terakhir pelaporan dan pengawasan terhadap dukungan pendanaan bagi Pemerintah Daerah untuk Pembangunan Sarpras Kelurahan dan Pemberdayaan Masyarakat dikelurahan .

Dalam pengelolaan keuangan DAUT ini dibutuhkan SDM yang mampu mengelola dan mengendalikan dana tersebut dalam pelayanan terhadap masyarakat kelurahan sesuai dengan aturannya.

3.4. Penelitian terdahulu

$$
\text { Dalam melakukan Analisis }
$$

Kesiapan SDM dan Regulasi Pengelolaan DAUT di Kota Payakumbuh Tahun 2019 ini dilakukan dengan pertimbangan dari beberapa hasil penelitian antara lain : berupa Perencanaan berpengaruh terhadap penyerapan anggaran SKPD di Kabupaten Aceh Utara; (Zarinah, 2015). Sebelumnya temuan dari Priatno pada tahun 2013 mengemukakan bahwa Perencanaan sangat berpengaruh terhadap penyerapan anggaran pada Satuan Kerja lingkup pembayaran KPPN Blitar. (Prasetyo, 2013). Penelitian Arif
Emkhad menemukan bahwa minimnya penyerapan APBD di Kota Dumai disebabkan karena lemahnya komitmen organisasi (Emkhad, 2011). Juliani menemukan bahwa tingkat penyerapan belanja/barang pada Pemerintah Daerah Yogyakarta faktor komitmen*manajemen akan mempengaruhi untuk pemberdayaan SDM berpengaruh positif terhadap kemampuan sumber daya yang dimilikinya, dan begitu juga sebaliknya tanpa komitmen maka pekerjaan besar akan sulit dilaksanakan.

\section{HASIL \& PEMBAHASAN}

\subsection{Hasil Analisa}

\subsubsection{Pengelolaan DAUT tahun 2019} di Kota Payakumbuh

Tatacara Penyaluran DAUT Sesuai dengan Peraturan Mentri Keuangan

No.187/PMK.07/2018, Pemerintah Kota Payakumbuh di kategorikan pada Perlu ditingkatkan, dimana alokasikan DAUT per kelurahan sebesar Rp.370.138.000,dengan total DAUT sebesar Rp. 17.396.486.000, seperti daftar tabel 3.1. terlampir.

Pelaksanaan kegiatan DAUT tahun 2019 anggarkan sebesar Rp.17.396.486.000 di alokasikan di kegiatan pembangunan sarana dan prasarana sebesar Rp.12.433.569.882.- dan pada kegiatan pemberdayaan masyarakat alokasikan sebesar Rp. 4.962.916.118.-, sampai 
per 31 Desember 2019 dengan capaian (tahap I dan Tahap II) adalah sebesar

Rp.14.040.710.005.- $\quad$ yaitu $80,71 \%$ seperti daftar tabel 3.2 . terlampir.

Untuk capaian tertinggi yaitu 92,33\% yaitu Kecamatan Payakumbuh Utara dengan jumlah Rp. 3.331.242.000.dengan realisasi Rp. 3.081.235.891.- terdapat sisa anggaran sebesar Rp.250.006.109.-, sedangkan capaian terendah adalah 74,33\% yaitu pada Kecamatan Payakumbuh Timur dengan jumlah anggaran Rp. 3.331.242.000.- dan realisasi sebesar Rp. 2.363.528.964.- dengan sisa anggaran sebesar Rp.967.713.036.-

Untuk masing-masing kecamatan dengan capaian sebagai berikut :

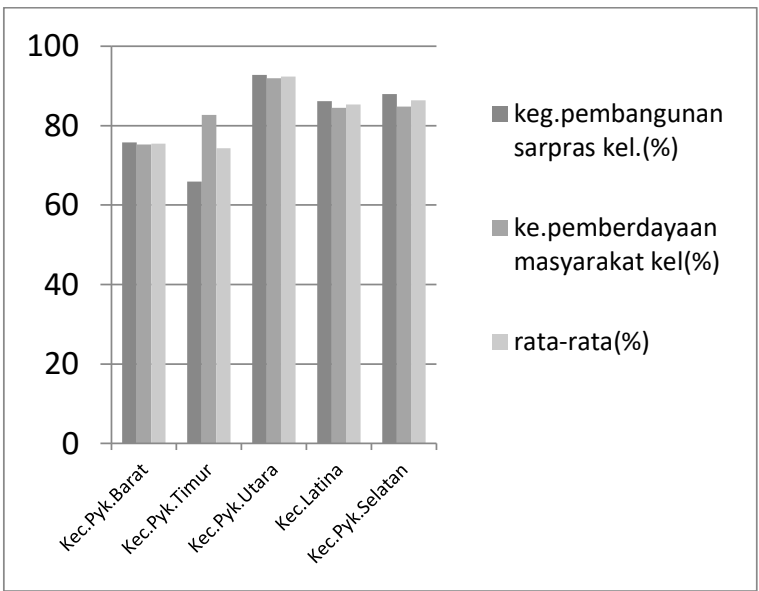

Gambar 3.1

Rata-rata capaian realisasi DAUT per Kecamatan Tahun 2019

\subsubsection{Pejabat pengelola keuangan} Kelurahan

Pada Pasal 229 UU No.23 Tahun 2014 menjelaskan bahwa Lurah membantu camat dalam melakukan pemberdayaan masyarakat dan memelihara prasarana dan fasilitas umum di kelurahan.

Pengelolaan DAUT merupakan Aparatur Sipil Negara (ASN). Pengelolaan DAUT tersebut dimulai dari penganggaran, penatausahaan dan pelaporan juga pengadaan barang/jasa dari proses pengadaan sampai pada penggunaan dan manfaat dari barang/jasa dari pelaksanaan kegiatan tersebut. Oleh sebab dibutuhkan SDM yang mampu melaksanakan pengelolaan keuangan dan punya sertifikasi. Untuk pelaksanaan dari kegiatan tersebut dibutuhkan Pejabat Pengelolaan Keuangan yang bertugas sebagai:

1. KPA (Kuasa Pengguna Anggaran) juga sebagai Pejabat Pembuat Komitmen yang ahli dalam pengadaan barang/jasa.

2. PPK (Pejabat Pengelola Keuangan), menyiapkan SPM, dokumen SPP- LS yang disampaikan oleh bendahara selanjutnya diteliti oleh PPK dan membantu Verifikasi SPP serta melakukan verifikasi penerimaan . 
3. Bendahara Pengeluaran

Pembantu sebagai kasir atau pembuat dokumen pengeluaran.

4. PPTK (Pejabat Pengelola Teknis Kegiatan) menpersiapkan dokumen untuk pengeluaran belanja pelaksanaan kegiatan dan pengendalian pelaksanaan kegiatan, serta menyusun laporan pelaksanaan kegiatan.

5. Pejabat Pengadaan adalah pejabat bertugas melaksanakan Pengadaan barang/jasa secara langsung ataupun Penunjukan Langsung penyedia barang/jasa.

6. Pejabat Pemeriksa pada Hasil Pengadaan (PjPHP) merupakan pejabat yang bertugas untuk memeriksa hasil dari pengadaan apakah sudah sesuai dengan kriteria yang dibutuhkan.

Daerah Kota Payakumbuh terdiri dari 5 (lima) Kecamatan dengan 47 Kelurahan. Kelurahan merupakan pemerintahan terendah, dengan jumlah ASN yang di tempatkan dengan struktur pada masing-masing Kecamatan adalah sebagai berikut :

Jabatan Struktural pada pemerintahan kelurahan dibutuhkan sebanyak 279 orang, sementara struktur yang terisi sebanyak 268 orang (96\%).

Dari jumlah kebutuhan masih ada kekurangan jabatan struktural sebanyak 11 orang dan Jabatan Fungsional Umum (JFU) tersedia hanya 12 orang sementara dibutuhkan sebanyak 94 orang yaitu sebagai Bendahara Pembantu dan PjPHP tiap kelurahan dengan kekurangan sebanyak 82 orang untuk masing - masing Kecamatan seperti daftar tabel 3.3. terlampir.

Pelaksanaan Kegiatan DAUT tahun 2019 terdapat kesulitan dalam pengelolaan keuangan daerah karena SDM yang bertugas sebagai PPK Kelurahan yang minim ilmu terhadap pengelolaan keuangan, juga dalam pelaksanaan pengadaan barang/jasa. Sebelumnya telah dilaksanakan Pelatihan pengelola keuangan untuk KPA, PPK dan PPTK, Bendahara Pembantu dan PjPHP sebagai pengelolaan keuangan di kelurahan yang telah dilakukan dengan dikebut (mengingat waktu pelaksanaan Kegiatan DAUT tersebut hanya 6 bulan), sementara pelatihan untuk pengelolaan aset dan pengadaan barang/jasa akan direncanakan pada tahun 2020

\subsubsection{Regulasi dari DAUT}

Pelaksanaan pengelolaan DAUT tahun 2019 dipertegas dengan Surat Edaran Mentri Dalam Negeri No.146/2694/SJ dan Peraturan Menteri Dalam Negeri No.130 Tahun 2018, sementara Kota Payakumbuh belum ada regulasi yang mengatur secara secara teknis pelaksanaan pengelolaan keuangan DAUT tahun 2019.

\subsection{Pembahasan analisa}

4.2.1. Pengelolaan DAUT tahun 2019 di Kota Payakumbuh 
Pengelolaan DAUT Tahun 2019 di Kota Payakumbuh yang anggarkan sebesar Rp.17.396.486.000 di alokasikan untuk kegiatan Pembangunan Sarpras Kelurahan sebesar Rp.12.433.569.882.- dan kegiatan Pemberdayaan Masyarakat dikelurahan sebesar Rp.4.962.916.118.-, sampai per 31 Desember 2019 dengan capaian (tahap I dan Tahap II) adalah sebesar Rp.14.040.710.005.- yaitu $80,71 \%$, secara umum sudah cukup baik.

Terdapat sisa anggaran sebesar Rp.3.355.775.995,-DAUT Tahun 2019 ini merupakan dana alokasi yang telah jelas peruntukannya dimana sudah seharusnya serapannya mencapai $100 \%$,

\subsubsection{Analisis Pejabat pengelola} keuangan Kelurahan

Pelaksanaan Kegiatan DAUT tahun 2019 terdapat kesulitan dalam pengelolaan keuangan daerah karena SDM yang bertugas sebagai PPK Kelurahan yang minim ilmu terhadap pengelolaan keuangan, juga dalam pelaksanaan pengadaan barang/jasa pemerintah.

ASN yang bertugas pada kelurahan untuk mengelola DAUT tahun 2019 belum punya pengetahuan tentang pengelola keuangan, Pejabat Pengadaan dan PjPHP belum punya sertifikasi keahlian pengadaan barang/jasa sehingga tidak paham dalam proses pengadaan barang/jasa yang mengakibatkan terhambatnya proses pencairan DAUT tersebut.

\subsubsection{Analisis Regulasi dari DAUT}

Dalam pelaksanaan pengelolaan DAUT tahun 2019 mengacu pada Surat Edaran Mentri Dalam Negeri No: 146/2694/SJ mengenai Petunjuk Pelaksanaan Peraturan Mentri Dalam Negeri No:130 Tahun 2018 tentang Kegiatan Pembangunan Sarana dan Prasarana serta Kegiatan Pemberdayaan Masyarakat Kelurahan Tahun Anggaran 2019. Secara teknis pelaksanaan pengelolaan keuangan DAUT tahun 2019 di Kota Payakumbuh perlu diatur dengan Peraturan Walikota Payakumbuh.

\section{KESIMPULAN DAN SARAN}

\subsection{Kesimpulan}

Dari analisa diatas, maka disimpulkan dari Ketersediaan SDM dan Regulasi Pengelolaan DAUT di Kota Payakumbuh adalah : DAUT Tahun anggaran 2019 untuk kegiatan Pembangunan Sarana dan Prasarana Kelurahan dan Kegiatan Pemberdayaan Masyarakat Kelurahan telah dianggarkan sebesar Rp.17.396.486.000, dengan realisasi sebesar Rp.14.040.710.005.- capaian hanya $80,71 \%$, sehingga terdapat sisa anggaran sebesar

Rp.3.355.775.995,-

Dalam pelaksanaan Kegiatan DAUT tahun 2019 terdapat kesulitan dalam pengelolaan keuangan daerah karena SDM yang bertugas sebagai PPK Kelurahan yang minim 
ilmu terhadap pengelolaan

keuangan, juga dalam pelaksanaan pengadaan barang dan jasa, karena ASN di kelurahan yang bertugas untuk mengelola DAUT tahun 2019 belum punya pengetahuan tentang pengelola keuangan, Pejabat pengadaan dan PjPHP belum punya sertifikasi Keahlian Pengadaan Barang/jasa Pemerintah sehingga tidak paham dalam proses pengadaan barang/jasa yang mengakibatkan terhambatnya proses pencairan DAUT tersebut.

Pedoman umum pelaksanaan pengelolaan DAUT tahun 2019 mengacu pada Surat Edaran Mentri Dalam Negeri No.146/2694/SJ yang merupakan penegasan dari Peraturan Mentri Dalam Negeri No:130 Tahun 2018 sebagai petunjuk pengelolaan dari Kegiatan Sarana dan Prasarana Kelurahan dan Pemberdayaan Masyarakat Kelurahan Tahun Anggaran 2019, sedangkan secara teknis pelaksanaan pengelolaan keuangan DAUT di Kota Payakumbuh tahun 2019 perlu diatur dengan Peraturan Walikota Payakumbuh.

Berdasarkan hasil analisa terhadap Ketersediaan SDM dan Regulasi Pengelolaan DAUT di Kota Payakumbuh tahun 2019 maka disarankan sebagai berikut :

1) Dalam pengelolaan keuangan Dana Alokasi Umum Tambahan dibutuhkan Pelatihan pengelolaan keuangan, pengelolaan aset dan pengadaan barang/jasa.

2) Kekurangan ASN khususnya Jabatan fungsional Umum/staf yang punya pekerjaan rangkap, disarankan untuk membuat perwako yang mengakomodir hal tersebut.

3) Disarankan untuk membuatkan regulasi pelaksanaan secara teknis pengelolaan DAUT di Kota Payakumbuh tahun 2019 yang merupakan dasar pengelolaan keuangan DAUT Tahun 2019.

4) Pengawasan oleh instansi pengawasan keuangan (Inspektorat, Badan Pemeriksa Keuangan) dan masyarakat sebagai pemantau terhadap regulasi

\section{DAFTAR PUSTAKA}

1.Sunyoto, Danang dan Burhanudin. 2015. Teori Perilaku Keorganisasian. Jakarta: Penerbit CAPS (Center Of Academic Publishing Service.

2. Nugroho, Budi. 2015. Mengenal Lebih Dekat Konsep Anggaran Daerah. https://konsultankti.wordpress.com/2015. Diakses tanggal 22 September 2016

3. Sumarsono, Sonny. 2003. Ekonomi Manajemen Sumber Daya Manusia dan Ketenagakerjaan. Yogyakarta : Graha Ilmu.

4. Hariandja, Marihot T.E, 2002. Manajemen Sumber Daya Manusia. Jakarta: Grasindo.

5. Herman Sofyandi 2009, Manajemen Sumber Daya Manausia, terjemahan Jakarta, PT Prenhalindo 
6. Mathis, R.L. \& J.H. Jackson. 2006. Human Resource Management: Manajemen Sumber Daya Manusia. Terjemahan Dian Angelia. Jakarta: Salemba Empat.

7. Zarinah, Monik. 2015. Pengaruh Perencanaan Anggaran dan Kualitas Sumber Daya Manusia Terhadap Tingkat Penyerapan Anggaran Satuan Kerja Perangkat Daerah Di Kabupaten Aceh Utara. Tesis. Banda Aceh. Pascasarjana Prodi Magister Akuntansi Universitas Syiah Kuala, Darussalam.

8. Priatno, A. Prasetyo. 2013. Analisis FaktorFaktor Yang Mempengaruhi Penyerapan Anggaran Pada Satuan Kerja Lingkup Pembayaran KPPN Blitar. Skripsi. Malang: Fakultas Ekonomi dan Bisnis Universitas Brawijaya.
9. Arif, Emkhad. 2012. Identifikasi FaktorFaktor Penyebab Minimnya Penyerapan Anggaran Pendapatan dan Belanja Daerah (APBD) Kabupaten/Kota di Provinsi Riau Tahun 2011. Tesis. Riau: Universitas Islam Riau.

10. Juliani, Dian. 2014. Pengaruh faktor-faktor kontekstual terhadap Persepsian penyerapan anggaran terkait pengadaan Barang/jasa. Skripsi. Yogyakarta: Fakultas Ekonomi Universitas Gadjah Mada

11. Mathis, L. Robert and J. H. Jackson. 2010. Human Resorce Management. Vol. 13. South Western Cengage Learning. 